\title{
The United Nations War Crimes Commission's Proposal for an International Criminal Court
}

\author{
by William Schabas OC MRIA ${ }^{*}$
}

A permanent international criminal court has now been a reality for more than a decade. Debates about its establishment have been underway for nearly a century. At the Paris Peace Conference of 1919 war crimes prosecutions and establishment of a 'high tribunal' for their prosecution were discussed at length by the Commission on Responsibilities of the Authors of War and on Enforcement of Penalties. ${ }^{1}$ The result, formulated in article 227 of the Treaty of Versailles, was a call to establish an international court to prosecute the German emperor, but it was to be an ad hoc institution rather than a permanent body. Dealing with what today we call the Armenian genocide, the Treaty of Sèvres was more ambitious, providing that '[i]n the event of the League of Nations having created in sufficient time a tribunal competent to deal with the said massacres, the Allied Powers reserve to themselves the right to bring the accused persons mentioned above before such tribunal, and the Turkish Government undertakes equally to recognise such tribunal'.

In 1920, the League of Nations appointed an Advisory Committee of Jurists to make proposals for the establishment of an international court of justice. At the initiative of one of its members, Baron Descamps of Belgium, the Committee recommended the creation of a 'High Court of International Justice' with jurisdiction to try crimes 'against international public order and the universal law of nations'. The proposal was discussed by the Council of the League and the Third Committee of the Assembly. Subsequently, the Advisory Committee declared the creation of a permanent international criminal court

\footnotetext{
* Professor of international law, Middlesex University, London; professor of international criminal law and human rights, Leiden University; emeritus professor of human rights law, National University of Ireland Galway.

${ }^{1}$ For a detailed history of the developments, see M. Cherif Bassiouni, ed., The Legislative History of the International Criminal Court: Introduction, Analysis, and Integrated Text, Vol. I, Ardsley, NY: Transnational Publishers, 2005, pp. 3-121; M. Cherif Bassiouni, 'The Making of the International Criminal Court', in M. Cherif Bassiouni, ed., International Criminal Law, Vol. III, Leiden: Martinus Nijhoff, 2008, pp. 269-292; Benjamin B. Ferencz, An International Criminal Court, A Step Toward World Peace - A Documentary History and Analysis, Vol. I, London/Rome/New York: Oceanea Publications, 1980, pp. 190 .
} 
to be 'premature'. 2

During the inter-war period, the international criminal court project was examined by several professional organisations, notably the International Law Association, ${ }^{3}$ the Inter-Parliamentary Union ${ }^{4}$ and the International Association of Penal Law. ${ }^{5}$ In 1937, the League of Nations adopted the Convention for the Prevention and Punishment of Terrorism. The treaty emerged following a French initiative prompted by the assassination of Prince Alexander of Yugoslavia, in Marseilles, in 1934. ${ }^{6}$ A protocol or annex to the Convention provided for the creation of an international criminal tribunal. ${ }^{7}$ The Convention was signed by thirteen States, but never entered into force. ${ }^{8}$

During the Second World War proposals to create an international criminal court returned to the international debate. There were serious discussions in the International Commission for Penal Reconstruction and Development and in the London International Assembly at which interested governments were represented. Both bodies favoured the establishment of an international court. The London International Assembly set up a commission to study prosecutions of war criminals, ${ }^{9}$ chaired by the Belgian jurist Marcel De Baer who was a keen supporter of the idea of an international court. According to the report of the Assembly, '[t]he terms of reference were not expressly stated but they were clearly indicated by the name of the Commission: the object was to prepare for the

\footnotetext{
${ }^{2}$ Historical Survey of the Question of International Criminal Jurisdiction, UN Doc. A/CN.4/7, p. 12.

3 'Report of the permanent International Criminal Court Committee', International Law Association, Report of the Thirty-fourth Conference, Vienna, 1926, London: Sweet \& Maxwell, 1927, p. 109. The Association returned to the subject six decades later: ILA, Report of the Sixty-first Conference, Paris, 1984, London: International Law Association, 1985, p. 257.

${ }^{4}$ Vespasian V. Pella, 'La criminalité de la guerre d'agression et l'organisation d'une répression internationale', report presented to the Twenty-third Conference of the Inter-Parliamentary Union, Compte rendu de la XXIIIe Conférence, Lausanne: Librairie Payot, 1926, p. 205.

${ }^{5}$ Vespasian V. Pella, La Guerre-Crime et les Criminels de Guerre, Neuchâtel, Switzerland: Éditions de la Baconnière, 1964, pp. 129 ff. Also: 'Historical Survey of the Question of International Criminal Jurisdiction', UN Doc. A/CN.4/7, pp. 75-88.

${ }^{6}$ See C. Eustathiades, La Cour pénale international pour la répression du terrorisme et le problème de la responsabilité internationale des États, Paris: Pedone, 1936; Antoine Sottile, 'Le terrorisme international', [1938] III Recueil de cours 89; H. Donnedieu de Vabres, 'La répression internationale du terrorisme: les Conventions de Genève (16 novembre 1937)', [1938] Revue de droit international et de législation comparée 37.

${ }^{7}$ Convention for the Creation of an International Criminal Court, League of Nations OJ Spec. Supp. No. 156 (1936), LN Doc. C.547(I).M.384(I).

${ }^{8}$ Historical Survey of the Question of International Criminal Jurisdiction - Memorandum submitted by the Secretary-General, UN Doc. A/CN.4/7/Rev.1, pp. 1-20.

${ }^{9}$ London International Assembly, Proceedings of the Second Meeting, 20 October 1941, p. 14, LSE Archives, MF434, LNU - League of Nations Union, Vol. 6/5.
} 
consideration of the Assembly reports and recommendations for the trial of persons accused of war crimes ${ }^{10}$. In October 1943, the London International Assembly adopted a 62 -article statute for an international criminal court prepared by de Baer. ${ }^{11}$

Then the forum of discussion shifted to the United Nations War Crimes Commission, which was just being established. Initially, it seems that the United Nations War Crimes Commission assumed that prosecutions would be conducted by national courts. There is nothing in the December 1943 report of the Sub-Committee established following the initial 26 October 1943 meeting of the Commission, with the task of 'indicating the lines on which the Commission should approach its task', to suggest that an international court was being contemplated. ${ }^{12}$ The Moscow Declaration had said that war crimes suspects were to be 'sent back to the countries in which their abominable deeds were done in order that they may be judged and punished according to the laws of these liberated countries and of free governments which will be erected therein'. However, this was 'without prejudice to the case of German criminals whose offenses have no particular geographical localization and who will be punished by joint decision of the government of the Allies'.

In February 1944, Committee II (Enforcement) began consideration of the subject of establishment of an international criminal court, using as a basis the draft convention prepared by the London International Assembly. ${ }^{13}$ It was accompanied by an explanatory report that spoke of the desirability of the 'speedy formation of an International Criminal Court alongside the United Nations Commission for the Investigation of War Crimes,

\footnotetext{
${ }^{10}$ London International Assembly, Reports of Commission I (Formerly Commission II) on the Trial and Punishment of War Criminals, December 1943, p. 5.

${ }^{11}$ Appendix II - Draft Convention for the Creation of an International Criminal Court, Drafted by the Chairman and amended by the Commission, October 1943, in London International Assembly, The Punishment of War Criminals, Recommendations of the London International Assembly, London, 1943, pp. 18-29. Also: Marcel de Baer, ed., Reports of Commission I - formerly Commission II - on the Trial and Punishment of War Criminals, London: London International Assembly, 1944; London International Assembly, Commission I for Questions Concerned with the Liquidation of the War, Draft Convention for the Creation of an International Criminal Court, November 1943.

${ }^{12}$ UNWCC, Report of the Sub-Committee (Amended as decided by the Commission on 2 December 1943).

${ }^{13}$ Sub-Committee on Enforcement, Draft Convention of an International Criminal Court Submitted to the London International Assembly (Drafted by M. de Baer and amended by Commission I of the L.I.A.), SC II/2, 14 February 1944.
} 
either in independent form or as part of the Permanent Court of International Justice'. ${ }^{14}$ The report continued

[T]he establishment of an International Criminal Court is of the greatest importance for the future, as it cannot be done without in the post-war World-Organisation. Any organization for the maintenance of International Order and Peace is in my opinion not complete if it does not possess an International Criminal Court before which those persons who disturb or threaten to disturb international order or peace can be summoned, and by which they can, if need be, be punished or eliminated. Indeed, the real significance of the punishment of war criminals, is only made clear when it is viewed in conjunction with the construction of a new International Order. ${ }^{15}$

These words seemed to imply a permanent body rather than an ad hoc institution aimed only at Nazi war criminals.

At the 22 February 1944 meeting of the Commission, Herbert Pell, the United States representative and the chair of Committee II (Enforcement), said that the Committee regarded consideration of the organisation of an international court as a necessary preliminary to its work. He sought the permission of the Commission to begin work on the question. Pell said he had not been able to organise a meeting with the Attorney General of the United Kingdom in order to discuss the matter, but said he could no longer ask the Committee to wait before taking up the matter. ${ }^{16}$ Prompted by the American and Australian delegates, on 22 February 1944 the United Nations War Crimes Commission mandated Committee II to begin discussions on the subject. ${ }^{17}$

In April 1944 Committee II began its consideration of a 'draft convention on the trial and punishment of war criminals'. ${ }^{18}$ It worked with a text prepared by Lawrence Preuss that was subsequently labelled the 'Preuss draft'. Preuss was an academic at the University of Michigan who had been seconded to the American delegation at the War Crimes Commission. As Herbert Pell's deputy, Preuss was in practice the watchdog of the Department of State. ${ }^{19}$ Pell was somewhat of a confidante of President Roosevelt and

\footnotetext{
${ }^{14}$ Report on the Constitution of and the Jurisdiction to be conferred on an International Criminal Court (submitted to the London International Assembly by Dr. J.M. de Moor), SC II/3, 25 February 1944, p. 4.

${ }^{15}$ Report on the Constitution of and the Jurisdiction to be conferred on an International Criminal Court (submitted to the London International Assembly by Dr. J.M. de Moor), SC II/3, 25 February 1944, p. 4.

${ }^{16}$ UNWCC, Minutes of Tenth Meeting, p. 2.

${ }^{17}$ United Nations War Crimes Commission, History of the United Nations War Crimes Commission and the Development of the Laws of War, London: His Majesty's Stationery Office, 1948, at p. 443.

${ }^{18}$ Draft Convention on the Trial and Punishment of War Criminals, II/11, 14 April 1944.

${ }^{19}$ See Graham Cox, 'Seeking Justice for the Holocaust: Herbert C. Pell versus the U. S. State Department', in this volume.
} 
had been appointed to head the United States delegation over the objections of senior Department of State officials. Preuss was a highly respected international law scholar with an impressive list of publications to his credit, including several in international criminal law. ${ }^{20}$ Although his obituary in the American Journal of International Law refers to his work at the United Nations War Crimes Commission, it does not mention that Preuss was the author of the draft statute of an international criminal court. ${ }^{21}$

The 'Preuss draft' had no preamble. It began with a chapter entitled 'Scope of War Crimes'. Two alternatives were suggested, differing essentially in form rather than content. The first consisted of two articles. Article 1 contained a chapeau that read as follows:

The offences listed hereinafter, committed in violation of the laws of war, by members of the armed forces, the civilian authorities or other persons acting under the authority of, or claim or colour of authority of, or in concert with, a state or other political entity engaged in war or armed hostilities with, or in hostile occupation of territory of, the United Nations, or any one of them at any time since July 7, 1937, shall be punishable as war crimes, in accordance with the provisions of this Convention...

The offences were confined to violations of 'the laws of war'. Although the matter was being discussed, there was as yet no agreement that crimes against humanity and crimes against peace would also be covered by the post-war prosecutions. ${ }^{22}$ Punishable acts

\footnotetext{
${ }^{20}$ Lawrence Preuss, 'La répression des crimes et délits contre la sûreté des états étrangers', (1933) 40 Revue générale de droit international public 606; Lawrence Preuss, 'International Law and German Legislation on Political Crime', (1935) 20 Grotius Society Transactions 85; Lawrence Preuss, 'Kidnaping of Fugitives from Justice on Foreign Territory', (1935) 29 American Journal of International Law 502; Lawrence Preuss, 'Der Umfang der Strafgewalt nach amerikanischer Rechtsauffassung', (1935) 5 Zeitschrift für ausländisches öffentliches Recht $u$. Völkerrecht 239; Lawrence Preuss, 'La non-extradition des nationaux dans les relations franco-américaines', (1937) 3 Revue internationale française du droit des gens 159, 244; Lawrence Preuss, 'American Conception of Jurisdiction with respect to Conflicts of Law on Crime', (1944) 30 Grotius Society Transactions 184.

${ }^{21}$ William W. Bishop Jr., 'Lawrence Preuss, 1905-1956', (1956) 50 American Journal of International Law 907.

${ }^{22}$ In parallel with the work of Committee II on the proposed court, Committee III examined expanding the categories of crimes to be punished. See: Resolution Moved by Mr. Pell, on $16^{\text {th }}$ March 1944, III/1, 18 March 1944; Extension of the Commission's Competence to Crimes not Committee against United Nations Nationals, Recommendation to be Forwarded by each Member of the War Crimes Commission to his own Government, C.16, 4 May 1944; Competence of the War Crimes Commission in Regard to the Crimes Referred to in Mr. Pell's Motion, Draft made at the Committee's request by Sir William Malkin, III/2, 29 March 1944; Scope of the Retributive Action of the United Nations According to their Official Declarations (The Problem of 'War Crimes' in connection with the second World War), Rapporteur: Dr. B. Ečer, III/3, 27 April 1944; Scope of the Retributive action of the United Nations, Conclusion proposed by the Drafting Committee, III/5, 12 May 1944; Report of the Sub-Committee Appointed to Consider Whether the Preparation and launching of the Present War Should be considered 'War Crimes', III/9, 15 September 1944.
} 
required a connection to a State or one of its subordinate entities that was at war against or in occupation of one of the United Nations. The temporal jurisdiction was to begin on 7 July 1937, the date of the Lukouchiao incident, also known as the Marco Polo bridge incident, a defining moment in the Japanese war on China. ${ }^{23}$

In the first alternative, the chapeau of article 1 was followed by 15 paragraphs beginning with '[m]urder or massacre', and including 'rape', 'enforced prosecution', 'terrorisation', 'wanton devastation' and a residual provision: '[o]ther serious acts, which by reason of their atrocious character, their ruthless disregard of the sanctity of human life and personality or their wanton interference with rights of property, are unrelated to reasonably conceived requirements of military necessity'. The enumeration of punishable acts appears to have been largely inspired by the one proposed in the report of the Commission on Responsibilities that met at the Paris Peace Conference in 1919. The list of crimes of the Commission on Responsibilities was much longer, with 32 distinct paragraphs, although it had no residual clause. ${ }^{24}$ Article 2 of the Preuss draft was entitled 'Persons liable'; it set out various classic forms of participation in criminal activity including ordering, aiding and abetting and incitement. The alternative version of Chapter I consisted of three articles, essentially similar in content to the first version but organised somewhat differently.

Judges were to be elected from among an assembly of 'Members of the Tribunal'. Each State Party was to appoint three 'Members'. At an initial meeting to be held at the seat of the Tribunal in London, the 'Members' were to elect the judges of the Tribunal for a three-year term. ${ }^{25}$ The judges were required to read both and to speak one of the official languages of the Tribunal - English and French - and were to be chosen from among persons qualified in their countries for appointment to high judicial office, or "experts in international law, in criminal law or in military law' ${ }^{26}$ The court's judiciary was to be organized in divisions of not less than five judges. ${ }^{27}$ The appointment of assessors who would sit with the judges and advise them on relevant matters but without a vote in the

\footnotetext{
${ }^{23}$ The Lukouchiao incident and its aftermath were discussed in the judgment of the International Military Tribunal for the Far East: United States of America et al. v. Araki et al., 12 November 1948, pp. 684-693.

${ }^{24}$ Commission on the Responsibility of the Authors of the War and on the Enforcement of Penalties, (1920)

14 American Journal of International Law 95, at pp. 114-115.

${ }^{25}$ Draft Convention on the Trial and Punishment of War Criminals, II/11, 14 April 1944, arts. 8, 9.

${ }^{26} \mathrm{Ibid}$. , art. 5.

${ }^{27}$ Ibid., art. 7.
} 
judgment was contemplated. ${ }^{28}$ The assembly of Members of the Tribunal was also charged with electing a United Nations Commission for the Prosecution of War Crimes. It was to consist of seven members, one of them to be designated Chief Prosecutor. However, no particular powers or authority were attributed to the Chief Prosecutor. The selection of cases for prosecution was to be made by the Commission. ${ }^{29}$

Chapter IV of the Convention addressed the subject of cooperation with the Tribunal. It contained specific provisions on surrender, extradition and transfer. A rather complex arrangement was set out to define the relationship between the international tribunal and national courts. Essentially, a regime of primacy was proposed, in that in the event of competing demands for prosecution, the international tribunal would take precedence over national courts. ${ }^{30}$

When first discussed by Committee II, there were objections from the British and Norwegian representatives who said it was too late to organize a court. They said it would be better to punish war criminals 'by political action', which may have been a euphemism for summary execution, an approach that the British continued to maintain well into $1945 .^{31}$ The representatives of Belgium, China, Czechoslovakia and the United States favoured the court proposal. The French delegate agreed in principle although with had reservations as to the applicable law. The Committee agreed to continue its discussions on the subject. ${ }^{32}$

The Committee considered a paper by Marcel de Baer of Belgium discussing various categories of crimes and the courts where they could be prosecuted. De Baer was especially interested in situations where there was no national court with jurisdiction or where the national court preferred the trial to take place before an international jurisdiction. ' $[\mathrm{I}] \mathrm{f}$ the countries that have been occupied agree that such a convenience should be afforded them one cannot see any good reason why it should be refused', he

\footnotetext{
${ }^{28}$ Ibid., art. 20.

${ }^{29}$ Ibid., arts. 22-23.

${ }^{30}$ Ibid., arts. 27-28.

${ }^{31}$ Aide-mémoire from the United Kingdom, April 23, 1945, in Report of Robert H. Jackson, United States Representative to the International Conference on Military Trials, Washington: U.S. Government Printing Office, 1949, pp. 18-20.

${ }^{32}$ United Nations War Crimes Commission, History of the United Nations War Crimes Commission and the Development of the Laws of War, London: His Majesty's Stationery Office, 1948, at p. 443.
} 
wrote. ${ }^{33}$ De Baer also noted that ' $[\mathrm{n}]$ o reference has been made ... to the trial of Germans who have committed crimes inside Germany (extermination of Jews), ${ }^{34}$

The record suggests that the focus of discussion was not on the detailed provision for the structure and operations of the court but rather on the definitions of crimes and the applicable law. Two provisions were involved, article 1, establishing the subject-matter definition, and article 29, dealing with the applicable law. The texts in the Preuss draft were revised in two ways. The reference to 7 July 1937 was removed from article 1 . With respect to the applicable law provision, the Preuss draft had basically copied the familiar text in the Statute of the Permanent Court of International Justice that recognized treaties, custom and general principles as sources of international law. The Committee decided to add an explicit recognition of the so-called Martens clause, taken from the preamble of the 1907 Hague Convention. ${ }^{35}$ The Martens clause states: 'Until a more complete code of the laws of war has been issued, the High Contracting Parties deem it expedient to declare that, in cases not included in the Regulations adopted by them, the inhabitants and the belligerents remain under the protection and the rule of the principles of the law of nations, as they result from the usages established among civilized peoples, from the laws of humanity, and the dictates of the public conscience.' Addition of the Martens clause was significant above all because it evoked 'laws of humanity' and seemed to presage the recognition of crimes against humanity.

At a meeting on 2 June 1944 the Committee agreed that 'such a court was desirable, if practicable'. It adopted the applicable law provision of the convention:

Law to be applied

Note of Meeting of Committee II held on 2 June 1944, Subject: Question of Establishing an International (Interallied) Court, II/16, 3 June 1944.

In the trial of persons charged with the offences specified in Article 1, the Tribunal and its Divisions shall apply:

(a) General international treaties or conventions declaratory of the laws of war, and particular treaties or conventions establishing rules of the laws of war expressly recognised by the belligerent states;

(b) International customs of war, as evidence of a general practice accepted as law;

\footnotetext{
${ }^{33}$ Note by H. de Baer on the Categories of Crimes Which Would Come before the International Criminal Court, II/13, 1 May 1944, p. 2.

${ }^{34}$ Ibid.

${ }^{35}$ Establishment of an International Court, Articles Adopted by the Committee, II/21, 22 June 1944; Establishment of an International Court, Articles Adopted by the Committee down to date (Revised edition), II/21(1), 27 June 1944.
} 
(c) The principles of the law of nations, derived from the usages established among civilised peoples, from the laws of humanity and from the dictates of the public conscience. (N.B. This phrase is taken from the eighth consideration set out in the Preamble of the 1907 Convention concerning the Laws and Customs of War on Land.)

(d) Judicial decisions as subsidiary means for the determination of the rules of the law of war. ${ }^{36}$

The minutes indicate that the Committee had not agreed upon the text of article $1 .^{37}$

In several meetings held during the months that followed, the Committee considered the definition of war crimes in article $1,{ }^{38}$ the modalities of prosecution, ${ }^{39}$ the election of judges, ${ }^{40}$ and the cases over which the court could exercise jurisdiction. ${ }^{41}$ The Secretary-General proposed a new provision that described the proposed court as a 'joint tribunal, to be known as the United Nations War Crimes Court..., ${ }^{42}$

The Preuss draft had envisaged a court with its own prosecuting authority. The idea was evidently controversial, and on 10 August 1944 the matter was debated by Committee II. The British representative, Sir Cecil Hurst, argued that 'the Governments would prefer to have their own lawyers to conduct the prosecution', giving by way of example the practice at the Permanent Court of International Justice. ${ }^{43}$ Dutt of India made a similar point referring to the Judicial Committee of the Privy Council. ${ }^{44}$ This was a strange argument because before the Permanent Court, where the litigation is between States, or the Privy Council, where one State may be the respondent, it is hard to imagine that governments would not want to choose their own lawyers. After all, they are the parties to the legal dispute and their interests are directly at stake. In criminal prosecution,

\footnotetext{
${ }^{36}$ Note of Meeting of Committee II held on 2 June 1944, Subject: Question of Establishing an International (Interallied) Court, II/16, 3 June 1944.

${ }^{37}$ Ibid.

${ }^{38}$ Article I of Draft Convention on the Trial and Punishment of War Criminals (Doc. II/11), II/17, 12 June 1944; Convention for the Establishment of a United Nations Joint Court, Draft Article Relating to the Courts [sic] Jurisdiction, Note by the Secretary-General, II/29, 23 August 1944.

${ }^{39}$ Questions as to the Jurisdiction of the Proposed Court prepared by the Sub-Committee, II/23, 29 June 1944, p. 3; Progress Report by the Secretary-General, II/27, 2 August 1944; Questions Concerning the Mode of Prosecution (M. de Baer), II/28, 29 August 1944.

${ }^{40}$ Draft Articles on the Election and Organisation of the Court (Preuss Chapter II) (Adopted on first reading on 24 August), II/31, 28 August 1944.

${ }^{41}$ Questions as to the Jurisdiction of the Proposed Court prepared by the Sub-Committee, II/23, 29 June 1944; Question of Establishing an International Criminal Court: Jurisdiction and Applicable Law, Progress made down to July 7, inclusive, II/24, 10 July 1944.

${ }^{42}$ Convention for the Establishment of a United Nations Joint Court, Draft Article Relating to the Courts [sic] Jurisdiction, Note by the Secretary-General, II/29, 23 August 1944, art. AA, p. 2.

${ }^{43}$ Notes of Discussion at Committee II on $10^{\text {th }}$ August, 1944, on the Question of Establishing a Prosecuting Office Attached to the Inter-Allied Court, II/30, 23 August 1944, p. 2.

${ }^{44}$ Ibid.
} 
where the parties are the accused individual and the prosecuting authority, the situation is hardly analogous. Even in the 1940s, most if not all of the domestic legal systems of States represented at the United Nations War Crimes Commission would have insisted on prosecutorial independence as an important feature of fair and impartial justice.

Other delegates, including Pell of the United States, favoured the idea of a prosecuting authority within the court. J.M. de Moor of the Netherlands argued that most of the States that made up the United Nations were 'not well equipped to conduct international prosecutions and were not rich enough to pay large fees to international lawyers'. He said that a prosecuting office would facilitate prosecution 'more effectively and more cheaply than if they were left to their own resources' adding that without such an office many criminals might escape prosecution altogether. ${ }^{45}$

By the beginning of September, most of the Preuss draft had been discussed, amended and adopted. The outstanding issues were the establishment of the prosecuting authority, the financing of the court, the plea of superior orders, and whether to include an obligation to cooperate with the court in surrendering indicted persons. A new article had been adopted that is relevant to the issue of the prosecuting authority in that it allowed States Parties to identify individual suspects for prosecution:

1. Except as otherwise provided by this Convention, the High Contracting Parties may at their own discretion bring persons accused of offences to which Article A applies to trial either before the Court or before a competent national court or military commission or other military tribunal.

2. The High Contracting Parties may agree upon a list of persons accused of war crimes for whose trial the Court shall alone be competent. ${ }^{46}$

Finally, some members indicated that they wished further discussion on whether to include general principles among the sources of law that the court could apply.

Important decisions about the shape of the proposed court were taken at a meeting on 7 September 1944. The institution was named the 'United Nations Joint Court'. ${ }^{47}$ No prosecuting authority was envisaged, although room was left for designation of a prosecutor when this was the preference of a State seeking the exercise of jurisdiction by

\footnotetext{
${ }^{45}$ Ibid.

${ }^{46}$ Articles adopted and Articles still to be considered, II/32, 1 September 1944, art. A.14, p. 4.

${ }^{47}$ Convention for the Establishment of a United Nations Joint Court, Amendments in draft articles (Doc. II/32) as a result of the meeting of $7^{\text {th }}$ September, 1944, II/33, 9 September 1944.
} 
the court. It was specified that the State concerned would have to pay the costs involved, making it unlikely that the measure would actually be implemented. If the State had to pay anyway, why wouldn't it prefer to control the prosecutor directly rather than simply hand the money over to the court? The import of the provision was that although the court might occasionally employ its own prosecutor, there would be no independent body with the authority to select cases. ${ }^{48}$ The Committee opted for a laconic subject-matter provision referring only to 'an offence against the laws and customs of war' and eschewing any attempt to provide an enumeration, even an exemplary one, of what this might encompass. The Committee also produced a preamble for the statute. ${ }^{49}$

In its report of 12 September 1944, the Commission said that it was 'satisfied that an inter-allied tribunal competent to exercise jurisdiction in any case of a violation of the laws of war should be set up'. It said it was 'now engaged in the preparation for consideration by Governments of a draft treaty or convention for the establishment of such an inter-allied court'. ${ }^{50}$ The report continued:

An alternative and more rapid method of setting up such a court would be by an order of the Supreme Commander in the field. A draft recommendation for this purpose is also in course of preparation.

The institution such an inter-allied tribunal or tribunals would be useful in other cases as well as those where the criminal law of the country may not render a particular war crime punishable at all. There will be cases in some Continental countries where an act which might constitute a serious violation of the laws of war might if dealt with under the ordinary criminal law of the country be subject only to a penalty which would be quite inadequate.

Such a tribunal might also be useful to the Allied Powers for dealing with the authors of some of the atrocities committed by the enemy which were not committed in any one particular country.

Whatever application maybe given by the Allied Governments to the passage in the Moscow Declaration that the treatment to be meted out to the authors of war crimes which have no particular geographical location is reserved for a decision of the Allied Powers, there will be some cases where the brutalities committed in countries occupied by the enemy on the Continent of Europe have been directly based upon decrees or ordinances issued by some Minister or functionary in Berlin. The public will not readily understand why the Nazi official at the head of the administration in a particular country is to be put on trial for a war crime such as the issue of a local ordinance ordering the compulsory deportation of a large number of the local inhabitants to Germany to work there, if the Minister or functionary who issued the decree on which the local ordinance was based is not also to be put on trial. For the latter purpose, however, some inter-allied tribunal will be advisable. ${ }^{51}$

\footnotetext{
${ }^{48}$ Draft Convention for the Establishment of a United Nations War Crimes Court, UN War Crimes Commission, Doc. C.50(1), 30 September 1944, p. 1.

${ }^{49}$ Convention for the Establishment of a United Nations Joint Court, Draft Presented by Committee II, Doc. C.50, 22 September 1944.

${ }^{50}$ Progress Report, Doc. C.48(1), 19 September 1944, p. 3. Also: Progress Report, Doc. C.48, 12 September 1944, p. 4

${ }^{51}$ Ibid.
} 
While this work on what the Commission was calling the 'Treaty court' was proceeding in Committee II, another proposal had begun to circulate by which a 'United Nations Military Tribunal' would be established. The document proposing this option noted that '[s]uch military tribunals provide just and expeditious means, in addition to any international Court which may be established by Convention, for the trial of persons..., ${ }^{52}$ A few weeks later the Drafting Committee issued a document further explaining the relationship between military tribunals and the international criminal court:

The United Nations War Crimes Commission will recommend to the United Nations the creation by convention of a United Nations War Crimes Court or Tribunal, for the trial of certain war criminals. However, it recognises that delay may occur while its recommendation and the proposed convention are being considered by the United nations thereby affecting the expeditious trial of cases. Accordingly, it is deemed necessary that some tribunal or tribunals be established in interim to try certain war criminals.

In case a United Nations War Crimes Court or Tribunal is established by convention it is considered desirable that, in addition thereto, other tribunals be established to try such war criminals as any United Nation may so request, to the end, that every means for the effective prosecution of war criminals are established and maintained, and that no war criminal escapes trial and punishment by reason of the inability effect a speedy trial. ${ }^{53}$

The subject underwent a full discussion by the plenary Commission at its September 1944 sessions. The chairman, Sir Cecil Hurst, questioned whether the proposal for military tribunals should be finalized before work on the 'Treaty court' was completed. Hurst said there was a need for both institutions, 'but not simultaneously'. He continued:

True, the cases so far submitted could all be tried by national courts, under the 'Moscow' system; but there was a class of persons who had directed criminal policies on the high level or who could not be adequately punished by some national courts, and for them an inter-allied court was needed. These cases would probably not exceed 30-50. But a civil court could only be set up by a convention, with consequent delay. This gap could be filled by the Military Court, which could be promptly set up by the Commander-inChief. $^{54}$

Pell added that the 'Treaty court' would require ratification by governments, and that the delay this might occasion could 'impose an intolerable strain on the patience of aggrieved

\footnotetext{
${ }^{52}$ Proposal for a United Nations Military Tribunal (Mt. Dutt's proposal as amended by a Drafting Committee), II/26, 1 August 1944.

${ }^{53}$ Proposal for a United Nations Military Tribunal (New text submitted by the Drafting Committee), II/26(1), 61 August 1944

${ }^{54}$ Minutes of Thirtieth Meeting held on $5^{\text {th }}$ September 1944, M.30, p. 2.
} 
peoples'. ${ }^{55}$ He took care to point out that in supporting the military tribunal approach, 'he was not seeking to "sabotage" the "Treaty" Court, of which he was a convinced advocate'. ${ }^{56}$ Based upon American archival materials, Aryieh Kochavi has suggested that Pell was trying to curry favour with President Roosevelt who had already indicated a strong preference for military tribunals. ${ }^{57}$ As far as Lord Wright of Australia was concerned, 'only military courts can do the job effectively and speedily'. He said he could see "no practical alternative at this stage'. ${ }^{58}$ Others, like André Gros of France, were very hesitant about the military tribunal approach and clearly favoured the "civil court' established by treaty. ${ }^{59}$ The Dutch representative, de Moor, said his government could accept the military tribunal proposal but that it 'must not interfere with the setting up of an International Civil Penal Court'. ${ }^{60}$

On 26 September 1944, the Commission adopted the statute of the court. ${ }^{61}$ The name of the proposed institution became the 'United Nations War Crimes Court'. The first paragraph of the preamble indicated that the signatories were 'desirous of ensuring that the perpetrators of war crimes committed by the enemy shall be brought to justice, ${ }^{62}$ implying that the Court would have a limited focus on war crimes perpetrated by the 'enemy' during the Second World War. But article 1 did not limit the jurisdiction so strictly, setting out that it extended to offences committed by those acting under the authority of 'a state or other political entity engaged in war or armed hostilities with any of the High Contracting Parties, or in hostile occupation of territory of any of the High Contracting Parties'. As there was no starting date for the temporal jurisdiction, theoretically the court would be able to prosecute crimes of the First World War, although that was obviously not the intent of the drafters. The paragraph based upon the Martens clause in the applicable law provision was retained and a new paragraph added

\footnotetext{
55 Ibid.

${ }^{56}$ Minutes of Thirty-first Meeting held on $12^{\text {th }}$ September 1944, M.31, p. 5.

${ }^{57}$ Arieh Kochavi, Prelude to Nuremberg: Allied War Crimes Policy and the Question of Punishment, Chapel Hill, NC: University of North Carolina Press, 1998.

${ }^{58}$ Minutes of Thirtieth Meeting held on $5^{\text {th }}$ September 1944, M.30, p. 3. See also the remarks of Lord Wright at 12 September 1944 meeting: Minutes of Thirty-first Meeting held on $12^{\text {th }}$ September 1944, M.31, pp. 4-5.

${ }^{59}$ Minutes of Thirty-first Meeting held on $12^{\text {th }}$ September 1944, M.31, pp. 3-4.

${ }^{60}$ Ibid., p. 6.

${ }^{61}$ Minutes of Thirty-third Meeting held on $26^{\text {th }}$ September 1944, M.33 (corrected text), p. 6.

${ }^{62}$ Draft Convention for the Establishment of a United Nations War Crimes Court, C.50(1), 30 September 1944.
} 
covering 'principles of criminal law generally recognised by civilised nations'. The proposal on military tribunals was postponed until the next meeting, when it was adopted after some fractious debate and only by eight votes to four. ${ }^{63}$

A rather summary explanatory report to accompany the draft convention prepared by Committee II was also adopted. It noted that the draft was 'self-explanatory' although it offered a few paragraphs to account for the decision not to provide a list of war crimes in article 1 ('this will give the Court the necessary latitude of action to carry out the intention of the Allied Governments as expressed in numerous public statements, notably the Declaration in Moscow dated the $1^{\text {st }}$ November 1943') and the absence of any provision on the defence of superior orders ('it is better to leave it to the Court itself in each case to decide what weight should be attached to a plea of superior orders. But the Commission wants to make it perfectly clear that its members unanimously agree that in principle this plea of itself does not exonerate the offender' $).{ }^{64}$

Pursuant to a unanimous decision of the Commission, ${ }^{65}$ on 6 October the Chairman wrote to the British foreign minister, Anthony Eden, conveying the following: 'In transmitting these documents I am asked to inform you that the Commission unanimously expressed the hope that you would be so good as to take the necessary steps to convene in the near future a diplomatic conference to consider, and if thought fit to conclude, a convention for the establishment of a United Nations War Crimes Court. ${ }^{66}$ Three months passed before Eden replied to the Chairman of the Commission, on 4 January 1945. The letter expressed the less than lukewarm attitude of the United Kingdom to the proposal for a treaty court. Eden said that members of the Commission were 'well aware that His Majesty's Government have throughout doubted both the desirability and the practicability, especially in view of the time factor, of the formal establishment of an Inter-Allied Court by treaty for this purpose'. He continued:

\footnotetext{
${ }^{63}$ Minutes of Thirty-fourth Meeting held on $6^{\text {th }}$ October 1944, M.34, pp. 1-6.

${ }^{64}$ Explanatory Memorandum to Accompany the Draft Convention for the Establishment of a United Nations War Crimes Court, C.58, 6 October 1944.

${ }^{65}$ Minutes of Thirty-fourth Meeting held on $6^{\text {th }}$ October 1944, M.34, p. 6.

${ }^{66}$ Draft Convention for the Establishment of a United Nations War Crimes Court and Recommendation for the Establishment by Supreme Military Commanders of Mixed Military Tribunals for the Trial of War Criminals, Letter from the Chairman of the Commission to the Rt. Hon. Anthony Eden, His Britannic Majesty's Principal Secretary of State for Foreign Affairs in the United Kingdom, C.60, 6 October 1944.
} 
It should be plain, however, that this is not a matter in which His Majesty's Government would desire, even if it were possible, to adopt a definite position without previous consultation with the Government of the United States, particularly as the military operations in Western Europe are on a joint basis and the Supreme Command is now in the hands of an American general. Moreover, until the two Government had reached, at any rate in principle, some conclusion as to the desirability of establishing and inter-Allied Court by treaty it was obviously impossible to pursue the suggestion made in your letter for the convocation of a conference to negotiate such a treaty. The matter has accordingly been the subject of full consultation with the Government of the United States, and as soon as the view of the two Governments have been definitely formed it is the desire of His Majesty's Government that the other Allied Governments concerned should be approached with a view to consultation as to the measures to be adopted. ${ }^{67}$

The 'Yalta Memorandum', prepared for President Roosevelt in January 1945, briefly discussed the work of the United Nations War Crimes Commission. Referring to its consideration of the proposed court, the memorandum said that ' $[\mathrm{t}]$ he labors of the Commission have not resulted in any governmental agreement as to the tribunals to try or the procedures for trying war criminals' ${ }^{68}$ It proposed the following:

We favor the trial of the prime leaders by an international military commission or military court, established by Executive Agreement of the heads of State of the interested United Nations. This would require no enabling legislation or treaty. If deemed preferable the tribunal could be established by action of the Supreme Authority (Control Council for Germany).

The court might consist of seven members, one each to be appointed by The British Commonwealth. the United States, the Soviet Union and France, and three to be appointed by agreement among the other United Nations who become parties to the proposed procedure.

The court may consist of civilian or military personnel, or both. We would prefer a court of military personnel, as being less likely to give undue weight to technical contentions and legalistic arguments. ${ }^{69}$

Five months later, the British and the Americans, together with France and the Soviet Union, met in London to adopt the Charter of the International Military Tribunal. In a general sense, the Tribunal's configuration was consistent with the Yalta memorandum and different in important respects from the spirit of the War Crimes Commission proposals.

The smaller countries, whose contributions in the United Nations War Crimes Commission had been so significant, were totally excluded from the negotiations of the London Charter. Later, their concurrence with the project was obtained through ratification of the Charter, as was noted in the opening words of the Nuremberg

\footnotetext{
${ }^{67}$ Letter dated 4 January, 1945 from Mr. Eden to Sir Cecil Hurst Dealing with Certain Proposals Submitted by the Commission to the Governments, C.68, 10 January 1945.

${ }^{68}$ Memorandum to President Roosevelt from the Secretaries of State and War and the Attorney General, January 22, 1945, in Report of Robert H. Jackson, United States Representative to the International Conference on Military Trials, Washington: U.S. Government Printing Office, 1949, pp. 3-9, at p. 4.

${ }^{69}$ Ibid., at pp. 7-8.
} 
judgment. ${ }^{70}$ According to the Charter, the prosecutors were designated by the four 'great' powers. In practice, the prosecutors selected the defendants pursuant to instructions from the governments that they represented. ${ }^{71}$ The Tribunal was intended to be temporary in nature. In practice, its work concluded with the judgment of 30 September-1 October 1946.

A brief flurry of activity directed at establishment of a permanent court followed, prompted by a reference in the 1948 Convention on the Prevention and Punishment of the Crime of Genocide. ${ }^{72}$ Then the project went into a lengthy hibernation, reviving in the early 1990s when the United Nations International Law Commission prepared a draft statute of a permanent court. After several years of intense negotiations, on 15 June 1998 the diplomatic conference that had been called for by the United Nations War Crimes Commission in October 1944 finally began. It resulted, five weeks later, in the adoption of the Rome Statute of the International Criminal Court.

Some of the same tensions that had been present in 1944 and 1945 emerged during the negotiations of the 1990s. In particular, the debate on both occasions involved a confrontation between the prerogatives of 'great powers', desirous of maintaining control over the court, and those of smaller and less powerful states, anxious for an institution premised on the equality of all of its members. In 1944 and 1945, the 'great powers' prevailed, essentially ignoring the proposal of the United Nations War Crimes Commission as they concluded an agreement on the Nuremberg Tribunal behind closed doors. Adherence of many other countries after the London Charter had been adopted amounted to a benediction of the proceedings but had no practical consequence in that the smaller States assumed no obligations and gained no rights as a result. The four powers retained absolute control over the institution, designating the prosecutors, the judges and the defendants.

Fifty years later, as discussions about a permanent international court resumed, the initial proposal of the International Law Commission contemplated a court whose

\footnotetext{
${ }^{70}$ France et al. v. Goering et al., (1948) 22 IMT 411.

${ }^{71}$ See: Kerstin von Lingen, Allen Dulles, the OSS, and Nazi War Criminals: The Dynamics of Selective Prosecution, Cambridge: Cambridge University Press, 2013; Michael Salter, Nazi War Crimes, US Intelligence and Selective Prosecution at Nuremberg: Controversies Regarding the Role of the Office of Strategic Services, Abingdon, UK: Routledge-Cavendish, 2007.

72 (1951) 78 UNTS 278, art. 6. Also: GA Res. 216 B (1948).
} 
priorities in terms of selecting targets for prosecution would be controlled by the United Nations Security Council. ${ }^{73}$ The usual suspects were at it again, this time joined by China. Through their domination of the Security Council, the permanent members established the International Criminal Tribunal for the former Yugoslavia in $1993 .{ }^{74}$ Instead of the 'major war criminals of the European axis', the jurisdictional frame adopted at London in 1945, it was 'persons responsible for serious violations of international humanitarian law committed in the territory of the former Yugoslavia since 1991'. At Nuremberg, each of the four powers had designated a prosecutor, whereas in 1993 the position was filled by a vote of the Security Council. The Nuremberg judges were also appointed by each of the four governments; the judges of the Yugoslavia tribunal were elected by the General Assembly but from a shortlist adopted by the Security Council. Late in the life of the Yugoslavia Tribunal, the Security Council dispensed with the endorsement of the General Assembly. ${ }^{75}$

By 1995, when drafting of the Rome Statute moved from the confines of the International Law Commission to the broad political space of the General Assembly, small and middle powers struggled to take control of the project, as they had done in the United Nations War Crimes Commission. This time, they were largely successful, substantially marginalising the role of the Security Council and with it the special status of the permanent members. Under the Rome Statute, judges and prosecutor are elected by all member states. Most important of all, the selection of situations for prosecution is made by an independent authority, without direct control by the Security Council and its permanent members. Nevertheless, after a decade of operation it is clear that the hegemonic aspirations of the 'great powers' have not entirely disappeared from international criminal justice. An early chapter in this saga took place in London in 1944 as the United Nations War Crimes Commission developed its draft statute for an international criminal court. The final chapters are still being written.

\footnotetext{
${ }^{73}$ Report of the International Law Commission on the work of its forty-sixth session (2 May-22 July 1994), in Yearbook . . 1994, UN Doc. A/CN.4/SER.A/1994/Add.l (Part 2), pp. 15-73.

${ }^{74}$ UN Doc. S/RES/827 (1993), annex.

${ }^{75}$ UN Doc. S/RES/1837 (2008); UN Doc. S/RES/1877 (2009); UN Doc. S/RES/1931 (2010), paras. 3-4; UN Doc. S/RES/1993 (2011), paras. 1-2.
} 